\title{
Availability of ISTE Digital Citizenship Standards Among Middle and High School Students and Its Relation to Internet Self-Efficacy
}

\author{
Fouad F. Aldosari ${ }^{1}$, Mohammad A. Aldaihan ${ }^{2}$ \& Riyadh A. Alhassan ${ }^{2}$ \\ ${ }^{1}$ Ministry of education, Riyadh, Saudi Arabia \\ ${ }^{2}$ King Saud University, Riyadh, Saudi Arabia \\ Correspondence: Riyadh A. Alhassan, King Saud University, Riyadh, Saudi Arabia. E-mail: \\ alhassan@ksu.edu.sa
}

Received: July 13, 2020 Accepted: August 12, 2020 Online Published: August 17, 2020

doi:10.5539/jel.v9n5p59 URL: https://doi.org/10.5539/jel.v9n5p59

\begin{abstract}
The purpose of this study was to gauge the level of availability of ISTE Digital Citizenship standards among middle and high school students in Riyadh, Saudi Arabia. The research employed a quantitative survey approach to measuring the availability of elements of digital citizenship. The survey was administered to a sample of 394 students from several middle and high schools. The survey items were built based on the four domains of digital citizenship by ISTE (Digital identity, Ethical behavior, Intellectual property, and Digital privacy and security). Findings revealed that students showing a high level of availability of digital citizenship in the first and second domains, as well as showing a high level of Internet self-efficacy. Based on the findings, it was recommended to put more emphasis on promoting digital citizenship among middle and high school students, especially raising awareness about intellectual property rights, cybersecurity, online bullying, digital identity, and good interaction with others over the Internet.
\end{abstract}

Keywords: digital citizenship, education, internet self-efficacy

\section{Introduction}

The continuous development of web technologies in the twenty-first century have changed the way people communicate and collaborate. As technologies continue to advance and change how societies communicate, there have been positive and negative uses of technology, which calls for educating members of the society in general about their digital interactions (Al-Dosari, 2017). Communication using technology expresses the behaviors and ethics of society members when interacting with one another. Therefore, technology must be used properly and effectively (Al-Qaid, 2014). Technology has become a tool for conducting life matters and it has advantages and disadvantages that depend on the nature of individuals' use of it (Al-Muslamani, 2014).

Young adults spend more time online than with their families or in their schools, which may deeply affect their social, emotional, and physical development (Orth \& Chen, 2013). The rate of use of mobile devices by children and teenagers has reached a level of up to eight hours per day, which reduces the possibility of them sitting with their parents. Thus, the effect of these devices may be negative or positive on them (Al-Qaid, 2014). Saudi Arabia has witnessed a remarkable growth in the number of technology users in the past few years. The percentage of students using the Internet is $93 \%$ and they represent the highest percentage among other groups in the country (General Authority for Statistics, 2019).

Given the need to have a system in place to properly control dealing with technology, the concept of Digital Citizenship has arisen with the emergence and penetration of the technology in all aspects of life leading to users' acquisition of a set of skills that are required for life in the information age (Lamushi, 2016). Digital Citizenship was defined by Al-Muslamani (2014, p. 23) as "preparing students for a society full of technology, by training them on adhering to the acceptable standards of behavior when using technology at school, home, or anywhere else." The rules of citizenship in the digital world are not different from any other rule of behavior in society in terms of respecting the responsibilities of the proper use of technology and compliance with ethical behavior while using it (Pescetta, 2011).

Prensky (2001) referred to the term "Digital Citizen" in his discussion about the difference between those who were raised while being surrounded by technologies which form an important part of their lives as they grew up 
using multiple tools and devices since a young age, and those who are showing interest in the technology, after it appeared in their lives, by trying to adapt it to their environment, where he called those ones "Digital Immigrants". A number of researchers (Lyons, 2012; Al-Muslamani, 2014; Payne, 2016) have agreed on a number of justifications that helped the emergence of the concept of digital citizenship, and formed its main features, such as easy access to the Internet service, easy communication with others via multiple and widespread web applications, easy access to information anywhere and anytime, the increase in the global rate of Internet use, which exposes many users to multiple and repeated negative situations, and the occurrence of many cases of dangers that have passed from the local community to the digital community, and began to grow and increase.

A good citizen in the age of technology is almost identical to any good citizen in a society or country, which requires compliance with laws, showing respect for others, and working in a civil and reasonable manner online (Payne, 2016). Furthermore, he or she combines skills and knowledge in digital situations to participate in the society as an active, connected, and lifelong learner (Pescetta, 2011; Netsafe, 2016). Furthermore, Al-Jazzar (2014) explained that digital citizenship is a modern culture that must be taken care of at home and at school and that a concerted effort must be made among civil society institutions to spread its culture by having a preventive policy, against the dangers of technology, and to take advantage of its positives. Moreover, The importance of digital citizenship lies in realizing what is the right or wrong behavior related to technology in its various forms (Al-Muslamani, 2014), as digital citizenship contributes to the preparation of individuals who are able to participate positively and effectively in the development and rise of societies and states (Al-Mallah, 2017).

Digital citizenship standards for students occupy a prominent position in ISTE standard, which aim is to make "Students recognize the rights, responsibilities and opportunities of living, learning and working in an interconnected digital world, and they act and model in ways that are safe, legal and ethical" (ISTE, 2019), and these standard are grouped into four domains:

1) Students cultivate and manage their digital identity and reputation and are aware of the permanence of their actions in the digital world.

2) Students engage in positive, safe, legal, and ethical behavior when using technology, including social interactions online or when using networked devices.

3) Students demonstrate an understanding of and respect for the rights and obligations of using and sharing intellectual property.

4) Students manage their personal data to maintain digital privacy and security and are aware of data-collection technology used to track their navigation online.

Some studies indicate a wide variety of features that are supposed to be possessed by the digital citizen and to make him or her has a high level of control over using technology effectively, such as critical thinking and decision-making (Kim \& Choi, 2018; Pescetta, 2011), being an effective consumer of internet sources (Al-Jazzar, 2014), demonstrating honesty and ethical behavior while using technology (Payne, 2016; Pescetta, 2011), being careful and honest when representing oneself and sharing personal data via Internet (Pescetta, 2011), having interpersonal communication skills, respecting cultures and privacy of others, and interacting with them positively (Al-Muslamani, 2014; Kim \& Choi, 2016), in addition to adhering to intellectual honesty and to the preservation of property rights, and urging others to do so (Lindsey, 2015; Pescetta, 2011).

Students should be encouraged to take advantage of their technology skills and properly employ them (Pescetta, 2011). Moreover, they have a role in doing projects that help highlight their technology achievements and proficiency, and in promoting the ethical behavior among their colleagues (Payne, 2016). For instance, proving personal responsibility for lifelong learning, showing positive attitudes towards the use of technology which support cooperation, learning, and productivity, practicing safe and legal acts and the proper use of technology, not posting negative thoughts online, maintaining their digital footprints, and respecting intellectual property rights (Al-Jazzar, 2014). To accomplish that, it is required to provide students with tools that help them use technology at school and courses on digital citizenship in addition to involving them in works at school that elevate their digital citizenship's level (Al-Mallah, 2017).

Al-Zahrani (2015) examined the level of availability of the elements of digital citizenship among male and female students at King Abdelaziz University, Saudi Arabia, and factors affecting their digital citizenship. The study found that male and female students have good levels of perceived digital citizenship, especially in terms of self-respect and having respect for others across the Internet. Moreover, it was found that factors that might affect digital citizenship were computer experience, average daily use of technology, students' attitudes toward 
the internet, and computer self-efficacy.

Jones and Mitchell's (2016) designed a scale for measuring digital citizenship among students, while focusing on two main domains: online respect and civic engagement over the Internet. The study found that online respect decreases with males and that females were better in both domains when compared to males, and both domains were negatively related to online harassment. Furthermore, the study discussed the implications of its results on the development and evaluation of educational programs for digital citizenship. In a similar fashion, Kim \& Choi study (Kim \& Choi, 2018) designed a scale to measure digital citizenship among teenagers from the perspective of in-service teachers and pre-service teachers. The scale consisted of four factors (S.A.F.E: Self-identity, Online Activity, Fluency for Digital environment, and Ethics for Digital environment). The results indicated the validity and effectiveness of the scale in measuring students' sense of digital citizenship. Moreover, Lyons study (Lyons, 2012) examined how middle-school students behave on the internet to identify the potential misbehaviors on the Internet. The following components were assessed: personal safety, digital citizenship, parental involvement, and electronic bullying. The study found that the higher the grade, the greater the risks of personal safety, misuse of digital citizenship, and electronic bullying.

\section{Research Problem}

Technology has recently become available to all society members. It is widely used mostly among teenage students. However, guiding students to use technology properly and positively is an important educational requirement to confront uses that accompany technology, such as the proliferation of online cultures, pornography, violation of individual privacy, and other uses that may affect the online identity of the technology user causing negative psychological effects on the family and society as well as political and security risks (Azzeddine, 2016).

Since there is no deterrent system for negative transgressions and inappropriate practices regarding the use of technology in Saudi Arabia, the government approved the Anti-Cyber Crime Law, which consists of 16 articles that are concerned with sanctioning those who use the technology in an improper way (Bureau of Experts, 2007). A report issued by the Ministry of Justice in the Kingdom of Saudi Arabia indicated that the number of information technology cases reached 1053 for the year 2016, including 275 cases in the city of Riyadh only (Al-Asiri, 2017).

The Digital Transformation Program 2020 in Saudi Arabia provides for enhancing the values and skills of students and building their national, and intellectual personality on the level of knowledge, skills, and values, which can be achieved in the digital world (Vision 2030, 2016a; Vision 2030, 2016b). While many studies (Pescetta, 2011; Lyons, 2012; Al-Zahrani, 2015; Jones \& Mitchell, 2016; Payne, 2016; Webster, 2018; Kim \& Choi, 2018) emphasize the role of both the student and the teacher in activating digital citizenship in the school environment and that knowing the level of digital citizenship among students leads to valuing their needs, and knowing the capabilities that may help in developing solutions to meet the demands of digital citizenship according to the school environment, which should create a suitable learning environment, raise awareness of its issues to reach safe practices and mitigate risky behaviors that may be caused by the use of technology.

Several studies (Al-Muslamani, 2014; Nordin, 2015; Al-Zahrani, 2015; Jones \& Mitchell, 2016; Al-Dosari, 2017; Kim \& Choi, 2018) measured the level of availability of digital citizenship standards for students at all levels of general education and higher education. But it was not based specifically on ISTE digital citizenship standards, and this is what the current study will add to the entirety of the previous literature. Accordingly, this research sought to know the level of digital citizenship of students by measuring it in their schools, through the middle and high school levels, and obtain perceptions of the extent to which students practice digital citizenship and its impact on them in their school lives and in their public lives as well. Moreover, the study sought to identify the relationship between internet self-efficacy and the level of availability of digital citizenship standards for students.

\section{Research Questions}

The research has answered the following two questions:

1) What is the level of availability of ISTE's digital citizenship standards among middle and high school students from their point of view?

2) Are there differences between the level of availability of ISTE's digital citizenship standards among students based on school stage, average daily use, and the number of social media networks to which they subscribe?

3) What is the relationship between availability of digital citizenship standards among students, and their level of internet self-efficacy? 


\subsection{Importance of the Research}

The importance of this research is derived from the following:

1) Enriching the educational field with the importance of digital citizenship in education as a recent topic of education in the twenty-first century.

2) Highlighting the importance of digital citizenship in electronic practices and interactions as a means of human progress in the modern era.

3) Providing a research tool based on ISTE digital citizenship standards to measure their availability for students.

4) Instructing those who are responsible for curriculum design to consider the digital citizenship standards when designing curricula for middle and high school phases.

\subsection{Research Terms}

Digital Citizenship: Ribble (2007/2012, p. 34) defines Digital Citizenship as: "The norms of appropriate and responsible behavior regarding the use of technology".

The research defines Digital Citizenship procedurally as: a set of knowledge, behaviors, and practices according to ISTE standards that characterizes the student to form the digital citizen model.

Internet Self-Efficacy: is defined by Kim and Glassman (2013) as the competencies and beliefs of the individual regarding the use of the internet. Self-efficacy in the field of internet use is defined procedurally as: the score a student gets in the self-efficacy scale for internet use which was developed by Kim and Glassman (2013).

\section{Methods}

The research adopted a quantitative approach. A survey was used to collect data on the perceptions of students in middle and high schools about their digital citizenship practices, and the extent of their knowledge of it, the extent of their mastery of technology uses and benefiting from it inside and outside the school.

\subsection{Research Population and Sample}

The research population consisted of all male middle and high school students in general education in Riyadh Region. The total number of male students was 204,900 (General Department of Education in Riyadh Region, 2018). The research sample was calculated from the student population using Krejcie and Morgan equation (1970), and the number of the sample 394 students chosen randomly from the study population. Since the educational system in Saudi Arabia was segregated by gender, the sample consisted only of male students, since a female sample was not accessible.

\subsection{Research Tool}

A survey was used to assess the level of availability of digital citizenship elements among middle and high school students. A number of studies (Al-Muslamani, 2014; Nordin, 2015; Al-Zahrani, 2015; Al-Dosari, 2017; Jones \& Mitchell, 2016; Kim \& Choi, 2018; ) applied a questionnaire to measure the level of availability of digital citizenship for students at all stages of general education and higher education, but those questionnaires were not specifically based on ISTE's digital citizenship standards. A review of previous literature in this field (Ribble, 2012/2007; Lyons, 2012; Jones \& Mitchell, 2016; Kim \& Choi, 2018), and some international experiments (NSW government, n.d.; Common Sense Media, 2016; IKeepSafe, n.d.;), the elements and themes of digital citizenship were investigated and classified as in Table 1. 
Table 1. The contents and frameworks of digital citizenship in some international studies and experiments

\begin{tabular}{|c|c|c|c|}
\hline Researcher/Institution & Factors/Elements & Researcher/Institution & Factors/Elements \\
\hline Ribble, 2012/2007 & $\begin{array}{ll}\text { 1. } & \text { Digital Access. } \\
\text { 2. } & \text { Digital Trade. } \\
\text { 3. } & \text { Digital Communication. } \\
\text { 4. } & \text { Digital Culture. } \\
\text { 5. } & \text { Digital Ethics. } \\
\text { 6. } & \text { Digital Law. } \\
\text { 7. } & \text { Digital Rights and Responsibilities. } \\
\text { 8. } & \text { Digital Health and Safety. } \\
\text { 9. } & \text { Digital Security. }\end{array}$ & Common Sense Media & $\begin{array}{ll}\text { 1. } & \text { Personal Photo and Identity. } \\
\text { 2. } & \text { Digital Footprint and Reputation. } \\
\text { 3. } & \text { Cyberculture } \\
\text { 4. } & \text { Privacy and Security. } \\
\text { 5. } & \text { Relationships and Communications. } \\
\text { 6. } & \text { Electronic bullying and Digital Drama. } \\
\text { 7. } & \text { Online safety. } \\
\text { 8. } & \text { Creative Credit and Copyrights. }\end{array}$ \\
\hline IKeepSafe & $\begin{array}{l}\text { 1. Use of Digital Balance. } \\
\text { 2. Practice of Ethical Digital Use. } \\
\text { 3. Protection of Personal Information. } \\
\text { 4. Maintaining Healthy and Safe } \\
\text { Relationships. } \\
\text { 5. Building a Positive Reputation. } \\
\text { 6. Achieving Digital Security. }\end{array}$ & Australian Model & $\begin{array}{ll}\text { 1. } & \text { Digital Behavior. } \\
\text { 2. } & \text { Digital Footprint. } \\
\text { 3. } & \text { Digital relationships. } \\
\text { 4. } & \text { Digital Health and Well-being } \\
\text { 5. } & \text { Digital Law. } \\
\text { 6. } & \text { Digital Financial Culture. }\end{array}$ \\
\hline Kim \& Choi, 2018 & $\begin{array}{l}\text { 1. Self-identity. } \\
\text { 2. } \quad \text { Online Activity. } \\
\text { 3. } \quad \text { Fluency in the Digital Environment. } \\
\text { 4. } \quad \text { Ethics of the Digital Environment. }\end{array}$ & Lindsey, 2015 & $\begin{array}{ll}\text { 1. } & \text { Copyright. } \\
\text { 2. } & \text { Digital Footprint/Social Media. } \\
\text { 3. } & \text { Acceptable Use Policies. } \\
\text { 4. } & \text { Promoting Responsible Student Behavior. }\end{array}$ \\
\hline Jones \& Mitchell, 2016 & $\begin{array}{ll}\text { 1. } & \text { Online Respect. } \\
\text { 2. } & \text { Electronic Bullying. } \\
\text { 3. } & \text { Online Civic Engagement. }\end{array}$ & Payne, 2016 & $\begin{array}{ll}\text { 1. } & \text { Internet Ethics. } \\
\text { 2. Information Security. } \\
\text { 3. } & \text { Cyber Security. }\end{array}$ \\
\hline
\end{tabular}

Since the research questions revolves around measuring the level of availability of digital citizenship standards for students according to ISTE standards, four aspects were included in the questionnaire according. The elements of digital citizenship were selected and assigned according to studies and experiments of these aspects. Furthermore, items that measure the availability of ISTE standards for digital citizenship of students were used. Figure 1 shows the final division of the domains.

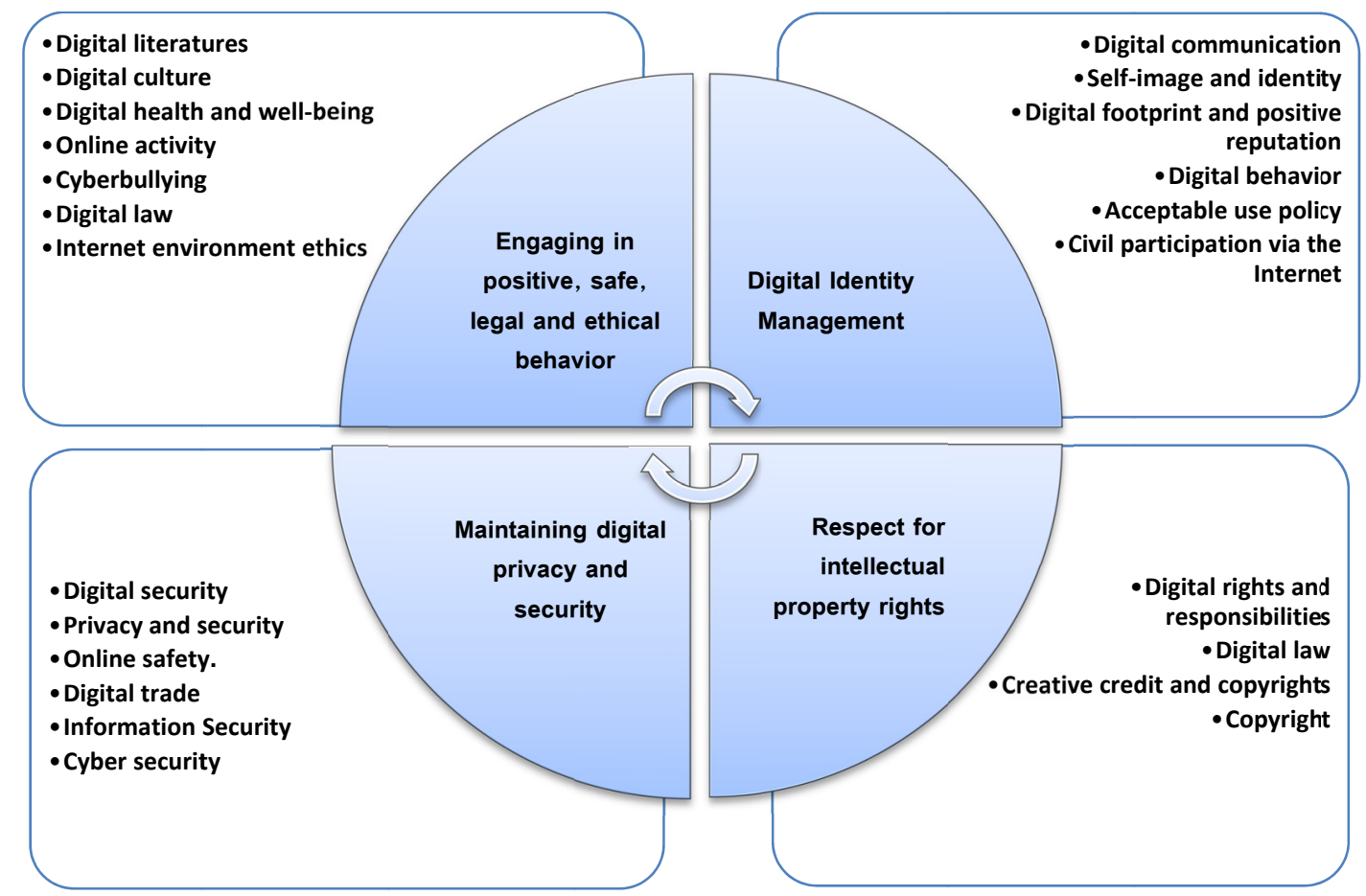

Figure 1. Suggested domains for measuring the level of availability of ISTE standards in digital citizenship for middle and high school students 
The questionnaire consisted of three sections: the first section related to the personal data of the student (name, school stage, average daily use of devices, computer development courses, number of accounts in social networks, types of devices used in digital communication), and the second section assessed the level of availability of ISTE standards in digital citizenship for students, and was divided into four parts: management of digital identity, engaging in positive, safe, legal and ethical behavior, respect for intellectual property rights, maintaining digital privacy and security. The third section assessed Students' internet self-efficacy.

Kim and Glassman (2013) developed a scale of the internet self-efficacy which is derived from Pandora's self-efficacy theory. De Marco, Robles and Antino (2014), and Kim and Choi (2018) showed the effectiveness of the internet self-efficacy scale in measuring digital citizenship, and the scale included 17 items. Kim and Choi (2018) revised the scale and reduced it to 14 items. The scale was utilized in this study to measure the relation between the availability of digital citizenship among students and their internet self-efficacy.

The questionnaire contained 80 items that measure the level of availability of ISTE digital citizenship standards among students and based on a five-point Likert scale.

\subsection{Validity and Reliability}

To verify the validity of the tool, the questionnaire was presented to 7 experts specialized in the field of curricula, teaching methods, and educational technology. Their remarks were taken into consideration, and after making the required adjustments to the tool, the number of items of the questionnaire reached 66 items. The tool was applied to an exploratory sample of 70 students outside the research sample, and the internal consistency was calculated using the Pearson correlation coefficient, and most items were positively correlated. However, four items $(12,15,16,19)$ were not significantly correlated, and were eliminated from the tool. The result of the Pearson correlation of the Internet self-efficacy scale indicated the consistency of all items in the scale at $\alpha=$ 0.01 .

Furthermore, Cronbach's alpha coefficient was calculated, and the result showed that the consistency coefficient of the first part was 0.85 , while the coefficient of the second part was 0.81 . Those two values are considered to be an acceptable level (Sharma, 2016). After verifying the validity and consistency of the questionnaire and making the necessary changes, the number of items in the final questionnaire was 62 items.

\section{Results and Discussion}

The answer to the first question of the study about the level of availability of digital citizenship standards for middle and high school students, 500 questionnaires were distributed to the two targeted sample. The number of retrieved questionnaires was 411 questionnaires. 17 questionnaires were excluded due to a lack of answers to some of the items in the questionnaire. The number of completed questionnaires and were analyzed was 394 questionnaires for both middle and high Schools.

First Domain: Digital Identity Management. 
Table 2. Frequencies, percentages, and averages of the responses of the sample arranged in descending order on items in the first domain

\begin{tabular}{|c|c|c|c|c|c|c|c|c|c|c|}
\hline \# & Items & & $\begin{array}{l}\text { Very } \\
\text { high }\end{array}$ & High & $\begin{array}{l}\text { Avera } \\
\text { ge }\end{array}$ & Low & N/A & M & $\mathrm{SD}$ & $\begin{array}{l}\text { Availability } \\
\text { Level }\end{array}$ \\
\hline \multirow[t]{2}{*}{5} & I always check the information on & Frequency & 225 & 44 & 61 & 23 & 36 & 4.03 & 1.34 & High \\
\hline & $\begin{array}{l}\text { social media before sending it to } \\
\text { others. }\end{array}$ & $\%$ & 57.8 & 11.3 & 15.7 & 5.9 & 9.3 & & & \\
\hline \multirow[t]{2}{*}{10} & I go for my real name when creating & Frequency & 180 & 41 & 64 & 34 & 72 & 3.57 & 1.57 & High \\
\hline & social media accounts. & $\%$ & 46.0 & 10.5 & 16.4 & 8.7 & 18.4 & & & \\
\hline \multirow[t]{2}{*}{9} & On my social media accounts, I make & Frequency & 91 & 39 & 59 & 34 & 163 & 2.64 & 1.64 & Average \\
\hline & $\begin{array}{l}\text { sure to choose an image that reflects } \\
\text { my values and principles. }\end{array}$ & $\%$ & 23.6 & 10.1 & 15.3 & 8.8 & 42.2 & & & \\
\hline \multirow[t]{2}{*}{1} & I think it's okay to chat online with & Frequency & 50 & 27 & 137 & 57 & 121 & 2.56 & 1.33 & High \\
\hline & strangers. & $\%$ & 12.8 & 6.9 & 34.9 & 14.5 & 30.9 & & & \\
\hline \multirow[t]{2}{*}{3} & I think it is a good idea to meet in & Frequency & 61 & 40 & 64 & 64 & 163 & 2.42 & 1.49 & High \\
\hline & $\begin{array}{l}\text { person with someone I originally met } \\
\text { online. }\end{array}$ & $\%$ & 15.6 & 10.2 & 16.3 & 16.3 & 41.6 & & & \\
\hline \multirow[t]{2}{*}{4} & I think online friendship should be & Frequency & 55 & 25 & 69 & 44 & 198 & 2.22 & 1.47 & High \\
\hline & kept as a secret from parents. & $\%$ & 14.1 & 6.4 & 17.6 & 11.3 & 50.6 & & & \\
\hline \multirow[t]{2}{*}{7} & Sometimes I lie online by pretending & Frequency & 27 & 18 & 36 & 55 & 255 & 1.74 & 1.22 & Very High \\
\hline & to be someone else & $\%$ & 6.9 & 4.6 & 9.2 & 14.1 & 65.2 & & & \\
\hline \multirow[t]{2}{*}{8} & I have written abusive comments for & Frequency & 22 & 15 & 35 & 71 & 247 & 1.70 & 1.14 & Very High \\
\hline & others on social media. & $\%$ & 5.6 & 3.8 & 9.0 & 18.2 & 63.3 & & & \\
\hline \multirow[t]{2}{*}{6} & I have spread rumours online. & Frequency & 17 & 9 & 16 & 25 & 322 & 1.39 & 0.99 & Very High \\
\hline & & $\%$ & 4.4 & 2.3 & 4.1 & 6.4 & 82.8 & & & \\
\hline \multirow[t]{2}{*}{2} & I think that it's ok to send my photo or & Frequency & 12 & 9 & 18 & 37 & 317 & 1.38 & 0.91 & Very High \\
\hline & video to someone I don't know. & $\%$ & 3.1 & 2.3 & 4.6 & 9.4 & 80.7 & & & \\
\hline \multicolumn{3}{|c|}{ * Overall Average } & & & & & & 3.88 & 0.58 & High \\
\hline
\end{tabular}

Table 2 shows that the research sample possessed a high availability level in the domain of "Digital Identity Management." The sample were keen to pay attention to their digital identity in general and are cautious about dealing and communicating with those who are unknown to them. Moreover, this indicates that only half of the students are keen to choose an image that reflects their values and principles on their accounts on social media. In addition, the data show that the sample are keen at this age on not communicating with strangers or those who are unknown to them online. They might be cautious themselves, or it could be through the attention paid by their parents.

Results also indicated that the students may sometimes use other identities than their real ones. However, those ones are a very small percentage. Lyons (2012) states that not revealing the digital identity may emphasize the abuse of technology, which promotes e-bullying and ethical abuse cases. Webster (2018) asserts that the digital identity of an individual has a major impact on what he or she presents. Furthermore, the results indicated that the sample, in general, do not offend others, do not spread rumors when they communicate online, and do not send their photos to people they do not know or to those whom they have previously seen online.

\section{Second Domain: Engaging in positive, safe, legal, and ethical behavior.}


Table 3. Frequencies, percentages, and averages of the responses of the sample students arranged in descending order on items in the second domain

\begin{tabular}{|c|c|c|c|c|c|c|c|c|c|c|}
\hline \# & Items & & $\begin{array}{l}\text { Very } \\
\text { high }\end{array}$ & High & Average & Low & N/A & $\mathrm{M}$ & SD & $\begin{array}{l}\text { Availability } \\
\text { Degree }\end{array}$ \\
\hline \multirow[t]{2}{*}{21} & \multirow{2}{*}{$\begin{array}{l}\text { I help my colleagues online when they ask } \\
\text { me to. }\end{array}$} & Frequency & 215 & 73 & 59 & 18 & 20 & 4.16 & 1.16 & High \\
\hline & & $\%$ & 55.8 & 19.0 & 15.3 & 4.7 & 5.2 & & & \\
\hline \multirow[t]{2}{*}{22} & \multirow{2}{*}{$\begin{array}{l}\text { I respect the opinions and feelings of } \\
\text { others online. }\end{array}$} & Frequency & 204 & 84 & 53 & 19 & 26 & 4.09 & 1.21 & High \\
\hline & & $\%$ & 52.8 & 21.8 & 13.7 & 4.9 & 6.7 & & & \\
\hline \multirow[t]{2}{*}{18} & \multirow{2}{*}{$\begin{array}{l}\text { I use the Internet to better understand my } \\
\text { school subjects at school. }\end{array}$} & Frequency & 176 & 78 & 77 & 34 & 26 & 3.88 & 1.26 & High \\
\hline & & $\%$ & 45.0 & 19.9 & 19.7 & 8.7 & 6.6 & & & \\
\hline \multirow[t]{2}{*}{19} & \multirow{2}{*}{$\begin{array}{l}\text { I am keen on learning new things } \\
\text { constantly while I am continuously } \\
\text { connected to the Internet. }\end{array}$} & Frequency & 158 & 86 & 82 & 42 & 21 & 3.82 & 1.23 & High \\
\hline & & $\%$ & 40.6 & 22.1 & 21.1 & 10.8 & 5.4 & & & \\
\hline \multirow[t]{2}{*}{17} & \multirow{2}{*}{$\begin{array}{l}\text { I would advise those who behave } \\
\text { inappropriately online. }\end{array}$} & Frequency & 174 & 54 & 74 & 34 & 57 & 3.65 & 1.47 & High \\
\hline & & $\%$ & 44.3 & 13.7 & 18.8 & 8.7 & 14.5 & & & \\
\hline \multirow[t]{2}{*}{15} & \multirow{2}{*}{$\begin{array}{l}\text { When I use a digital device, I make sure } \\
\text { to be in the correct and comfortable } \\
\text { physical position. }\end{array}$} & Frequency & 144 & 68 & 92 & 37 & 49 & 3.57 & 1.39 & High \\
\hline & & $\%$ & 36.9 & 17.4 & 23.6 & 9.5 & 12.6 & & & \\
\hline \multirow[t]{2}{*}{14} & \multirow[t]{2}{*}{ I spend a lot of time using technology. } & Frequency & 127 & 57 & 116 & 48 & 41 & 3.47 & 1.34 & High \\
\hline & & $\%$ & 32.6 & 14.7 & 29.8 & 12.3 & 10.5 & & & \\
\hline \multirow[t]{2}{*}{26} & \multirow{2}{*}{$\begin{array}{l}\text { I believe that hacking into other people's } \\
\text { information is an unethical behavior. }\end{array}$} & Frequency & 181 & 34 & 39 & 29 & 98 & 3.45 & 1.70 & High \\
\hline & & $\%$ & 47.5 & 8.9 & 10.2 & 7.6 & 25.7 & & & \\
\hline \multirow[t]{2}{*}{13} & \multirow{2}{*}{$\begin{array}{l}\text { I warn people around me of the negative } \\
\text { situations I have experienced online. }\end{array}$} & Frequency & 140 & 62 & 71 & 46 & 70 & 3.40 & 1.51 & High \\
\hline & & $\%$ & 36.0 & 15.9 & 18.3 & 11.8 & 18.0 & & & \\
\hline \multirow[t]{2}{*}{27} & \multirow{2}{*}{$\begin{array}{l}\text { I take care not to spread private } \\
\text { information about others out of harm }\end{array}$} & Frequency & 159 & 31 & 35 & 35 & 125 & 3.17 & 1.76 & Average \\
\hline & & $\%$ & 41.3 & 8.1 & 9.1 & 9.1 & 32.5 & & & \\
\hline \multirow[t]{2}{*}{11} & \multirow{2}{*}{$\begin{array}{l}\text { I create videos or pictures online to share } \\
\text { it with others. }\end{array}$} & Frequency & 111 & 55 & 72 & 42 & 110 & 3.04 & 1.59 & Average \\
\hline & & $\%$ & 28.5 & 14.1 & 18.5 & 10.8 & 28.2 & & & \\
\hline \multirow[t]{2}{*}{20} & \multirow{2}{*}{$\begin{array}{l}\text { I know what is meant by Digital } \\
\text { Citizenship. }\end{array}$} & Frequency & 81 & 45 & 54 & 64 & 127 & 2.70 & 1.57 & Average \\
\hline & & $\%$ & 21.8 & 12.1 & 14.6 & 17.3 & 34.2 & & & \\
\hline 16 & I suffer from hand or neck problems with & Frequency & 62 & 28 & 76 & 83 & 143 & 2.45 & 1.44 & Low \\
\hline & prolonged use of any digital device. & $\%$ & 15.8 & 7.1 & 19.4 & 21.2 & 36.5 & & & \\
\hline 24 & I have made fun of people online. & Frequency & 61 & 37 & 42 & 65 & 174 & 2.33 & 1.52 & High \\
\hline & & $\%$ & 16.1 & 9.8 & 11.1 & 17.2 & 45.9 & & & \\
\hline 23 & Others have made fun of me over the & Frequency & 56 & 27 & 65 & 49 & 188 & 2.26 & 1.48 & High \\
\hline & internet. & $\%$ & 14.5 & 7.0 & 16.9 & 12.7 & 48.8 & & & \\
\hline 28 & I have learned improper behaviors from & Frequency & 54 & 29 & 58 & 64 & 183 & 2.24 & 1.46 & High \\
\hline & others online. & $\%$ & 13.9 & 7.5 & 14.9 & 16.5 & 47.2 & & & \\
\hline 25 & I have searched for things that are against & Frequency & 32 & 10 & 26 & 46 & 270 & 1.67 & 1.23 & Very high \\
\hline & the noble religion. & $\%$ & 8.3 & 2.6 & 6.8 & 12.0 & 70.3 & & & \\
\hline 12 & I think it is okay to post information and & Frequency & 18 & 15 & 28 & 43 & 287 & 1.55 & 1.08 & Very high \\
\hline & $\begin{array}{l}\text { photos of someone online without his } \\
\text { permission. }\end{array}$ & $\%$ & 4.6 & 3.8 & 7.2 & 11.0 & 73.4 & & & \\
\hline 29 & I use social media to intimidate or & Frequency & 24 & 9 & 27 & 33 & 298 & 1.54 & 1.12 & Very high \\
\hline & threaten others. & $\%$ & 6.1 & 2.3 & 6.9 & 8.4 & 76.2 & & & \\
\hline & erall Average & & & & & & & 3.64 & 0.49 & High \\
\hline
\end{tabular}

It is evident from Table 3 that the sample possessed a high level of availability in the second domain "engaging in positive, safe, legal and ethical behavior," and this indicates that the sample uses the technology positively according to ISTE standard. Meanwhile, items 27 and 11 received an average level of availability, and these items indicate the level of students' communication with others via the Internet, and how it's related to respecting others, which is consistent with the findings of the Jones and Mitchell study (2016) on the low levels of respect among male students. Also, Rebel (2012/2007) emphasizes that when dealing with technology, users need to take into account the feelings of others, as most of the negative practices are due to the habit of practice, a lack of education towards respecting others, or derogation from their significance.

The results showed that a part of the sample practices positive communication and respect for others, while others may harm others via the Internet, as illustrated by responses to item number 27 . Therefore, the bad behaviors of students should be discouraged by promoting positive behavior at school. Jones and Mitchell (2016) discern that it is necessary to focus on practicing normal and tolerant behaviors toward others and increase civic 
skills and community activities, instead of repeated warnings of negative behaviors.

The results also showed that most of the sample were not exposed to mockery situations by others, nor did they learn inappropriate behaviors from others, or even never mock others. However, this outcome contradicts that a part of the sample has mocked people on the Internet as in indicated by responses to items number 24 and 27, regarding the dissemination of information that may harm others. Also, response to item number 16 are worth focusing on, as it shows that the sample was exposed to health problems caused by prolonged use of technology devices.

The results show that 197 students out of 394 did not not know what the concept of digital citizenship is, and 81 of them have only heard of it. The lack of knowledge of the concept of digital citizenship may expose students to its violations and to negative practices of technology. Jones and Mitchell (2016) pointed out the importance of clarifying the concept of digital citizenship, and not to confuse it with digital literacy.

\section{Third Domain: Intellectual Property Rights Respect}

Table 4. Frequencies, percentages, and averages of the responses of the sample arranged in descending order on items in the third domain

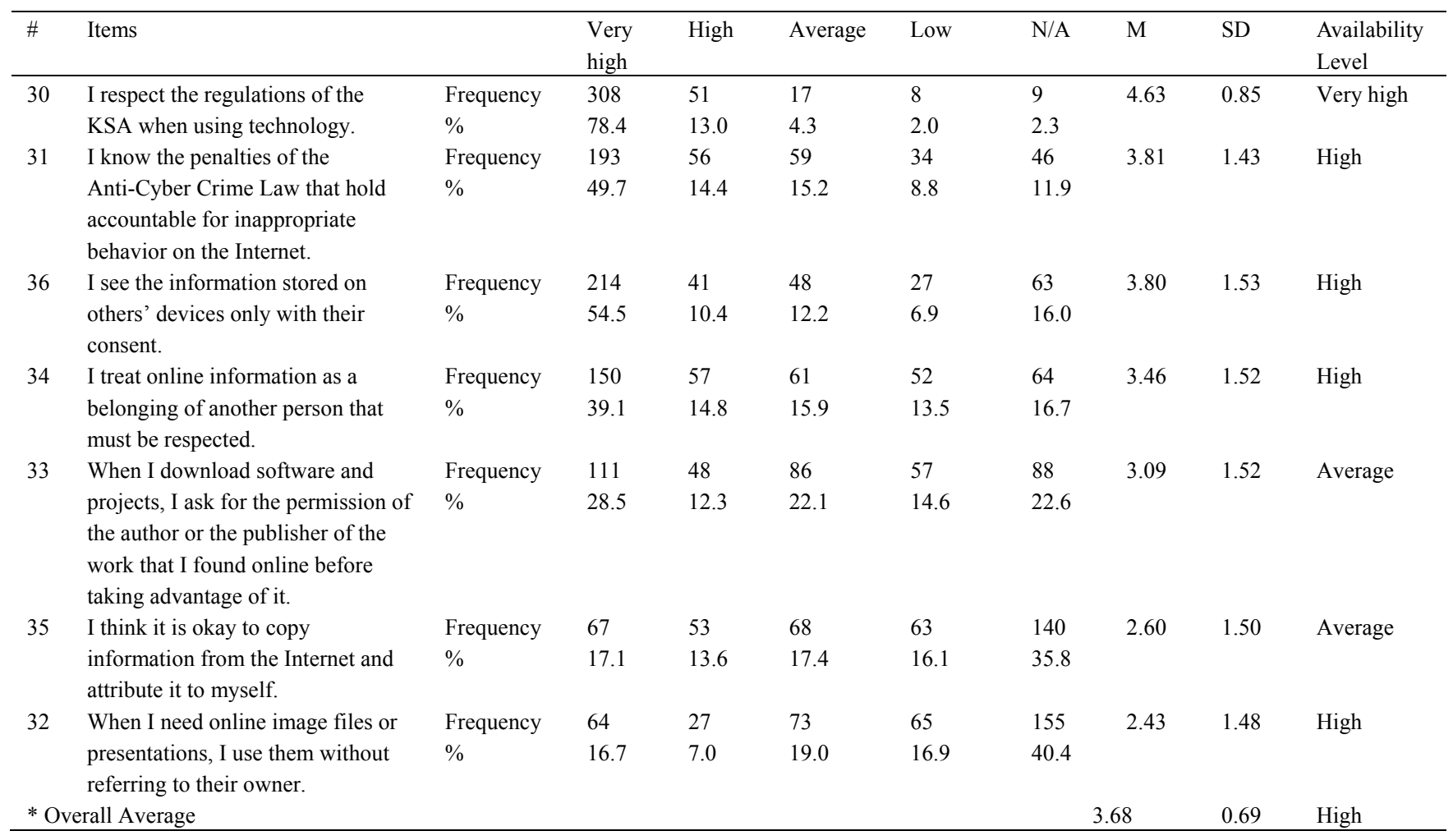

Table 4 shows that the sample possessed a high level of availability regarding the third domain: "Intellectual Property Rights Respect," which means that the sample uses technology properly as per ISTE standard and that they respect the laws that preserve their rights, as well as others'. However, there appears to be a contradiction between the students' responses to some of the items, as item 31 that has a high level of availability and indicates that students know the penalties of the Anti-Cyber Crime Law, is inconsistent with response to item 33, namely the authorization request of the author or the publisher to download projects and software, as it received an average level of availability. It can be concluded that the students were not accurate regarding the answer to item 31. Payne (2016) noted that students do not have considerations of intellectual property rights, including copyrights, and that high and middle schools must teach students about violations of intellectual property laws. Al Jazzar (2014) emphasizes the role of schools in warning from violations of intellectual property rights.

Fourth Domain: Maintaining Digital Privacy \& Security 
Table 5. Frequencies, percentages, and averages of the responses of the sample arranged in descending order on items in the fourth domain

\begin{tabular}{|c|c|c|c|c|c|c|c|c|c|c|}
\hline$\#$ & Items & & $\begin{array}{l}\text { Very } \\
\text { high }\end{array}$ & High & Average & Low & N/A & M & SD & $\begin{array}{l}\text { Availability } \\
\text { Level }\end{array}$ \\
\hline \multirow[t]{2}{*}{37} & \multirow{2}{*}{$\begin{array}{l}\text { I exercise caution when } \\
\text { shopping online. }\end{array}$} & Frequency & 277 & 37 & 31 & 11 & 36 & 4.30 & 1.28 & Very high \\
\hline & & $\%$ & 70.7 & 9.4 & 7.9 & 2.8 & 9.2 & & & \\
\hline \multirow[t]{2}{*}{42} & \multirow{2}{*}{$\begin{array}{l}\text { I activate security settings for } \\
\text { all of my social media } \\
\text { accounts. }\end{array}$} & Frequency & 242 & 48 & 40 & 22 & 37 & 4.12 & 1.34 & High \\
\hline & & $\%$ & 62.2 & 12.3 & 10.3 & 5.7 & 9.5 & & & \\
\hline \multirow[t]{2}{*}{38} & \multirow{2}{*}{$\begin{array}{l}\text { I make sure to download files } \\
\text { from verified websites. }\end{array}$} & Frequency & 217 & 63 & 49 & 28 & 33 & 4.03 & 1.32 & High \\
\hline & & $\%$ & 55.6 & 16.2 & 12.6 & 7.2 & 8.5 & & & \\
\hline \multirow[t]{2}{*}{47} & \multirow{2}{*}{$\begin{array}{l}\text { I use a complex password that } \\
\text { is difficult to be discovered. }\end{array}$} & Frequency & 203 & 54 & 63 & 25 & 43 & 3.90 & 1.39 & High \\
\hline & & $\%$ & 52.3 & 13.9 & 16.2 & 6.4 & 11.1 & & & \\
\hline \multirow[t]{2}{*}{40} & \multirow{2}{*}{$\begin{array}{l}\text { I make sure to back up my files } \\
\text { and digital photos to avoid } \\
\text { theft, loss, or damage. }\end{array}$} & Frequency & 210 & 52 & 48 & 34 & 45 & 3.89 & 1.43 & High \\
\hline & & $\%$ & 54.0 & 13.4 & 12.3 & 8.7 & 11.6 & & & \\
\hline \multirow[t]{2}{*}{39} & \multirow{2}{*}{$\begin{array}{l}\text { I make sure to install an } \\
\text { antivirus software on my } \\
\text { devices. }\end{array}$} & Frequency & 207 & 49 & 54 & 28 & 49 & 3.87 & 1.45 & High \\
\hline & & $\%$ & 53.5 & 12.7 & 14.0 & 7.2 & 12.7 & & & \\
\hline \multirow[t]{2}{*}{48} & \multirow{2}{*}{$\begin{array}{l}\text { I exercise caution when giving } \\
\text { out personal information to } \\
\text { strangers on the Internet. }\end{array}$} & Frequency & 217 & 41 & 45 & 29 & 60 & 3.83 & 1.52 & High \\
\hline & & $\%$ & 55.4 & 10.5 & 11.5 & 7.4 & 15.3 & & & \\
\hline \multirow[t]{2}{*}{45} & \multirow{2}{*}{$\begin{array}{l}\text { I change my passwords } \\
\text { regularly to protect my privacy. }\end{array}$} & Frequency & 196 & 49 & 60 & 33 & 50 & 3.79 & 1.46 & High \\
\hline & & $\%$ & 50.5 & 12.6 & 15.5 & 8.5 & 12.9 & & & \\
\hline \multirow[t]{2}{*}{43} & \multirow{2}{*}{$\begin{array}{l}\text { I do not share my passwords } \\
\text { with others on the Internet. }\end{array}$} & Frequency & 209 & 24 & 42 & 32 & 81 & 3.64 & 1.65 & High \\
\hline & & $\%$ & 53.9 & 6.2 & 10.8 & 8.2 & 20.9 & & & \\
\hline \multirow[t]{2}{*}{46} & \multirow{2}{*}{$\begin{array}{l}\text { I avoid opening any unknown } \\
\text { or unreliable files from the } \\
\text { internet. }\end{array}$} & Frequency & 158 & 46 & 63 & 51 & 72 & 3.43 & 1.56 & High \\
\hline & & $\%$ & 40.5 & 11.8 & 16.2 & 13.1 & 18.5 & & & \\
\hline \multirow[t]{2}{*}{49} & \multirow{2}{*}{$\begin{array}{l}\text { I click directly on the links } \\
\text { received via social media } \\
\text { without checking them. }\end{array}$} & Frequency & 48 & 29 & 70 & 78 & 165 & 2.27 & 1.39 & High \\
\hline & & $\%$ & 12.3 & 7.4 & 17.9 & 20.0 & 42.3 & & & \\
\hline \multirow[t]{2}{*}{44} & \multirow{2}{*}{$\begin{array}{l}\text { Whenever any website or } \\
\text { application requests my } \\
\text { personal data, I type it } \\
\text { unhesitatingly. }\end{array}$} & Frequency & 47 & 33 & 59 & 75 & 171 & 2.25 & 1.41 & High \\
\hline & & $\%$ & 12.2 & 8.6 & 15.3 & 19.5 & 44.4 & & & \\
\hline \multirow[t]{2}{*}{41} & \multirow[b]{2}{*}{$\begin{array}{l}\text { I think it is okay to share some } \\
\text { personal information with } \\
\text { strangers on the Internet, such } \\
\text { as my address, the name of my } \\
\text { school, and my phone number. }\end{array}$} & Frequency & 48 & 17 & 56 & 52 & 216 & 2.05 & 1.41 & High \\
\hline & & $\%$ & 12.3 & 4.4 & 14.4 & 13.4 & 55.5 & & & \\
\hline \multicolumn{3}{|c|}{ Overall Average } & & & & & 3.86 & & 0.75 & High \\
\hline
\end{tabular}

It is clear from Table 5 that the research sample possessed a high level of availability regarding the fourth domain: "Preserving digital privacy and security. It is evident that the sample are cautious about the security aspect in general, and their responses indicated that they are aware of how to exercise protection while dealing with files on the Internet." With regard to dealing with other people, the responses of the sample showed a high level of availability, indicating the awareness and caution of most of the sample individuals regarding the level of protection and security while dealing with strangers.

\section{Internet self-efficacy for middle and high school students}


Table 6. Frequency, percentages, and averages of the responses of the sample arranged in descending order on items in the second domain

\begin{tabular}{|c|c|c|c|c|c|c|c|c|c|c|}
\hline \# & Items & & $\begin{array}{l}\text { Very } \\
\text { high }\end{array}$ & High & Average & Low & N/A & M & $\mathrm{SD}$ & Availability \\
\hline 14 & $\begin{array}{l}\text { I use Google search engine, or } \\
\text { another search engine, } \\
\text { successfully to find the } \\
\text { information I need. }\end{array}$ & $\begin{array}{l}\text { Frequency } \\
\%\end{array}$ & $\begin{array}{l}241 \\
62.0\end{array}$ & $\begin{array}{l}52 \\
13.4\end{array}$ & $\begin{array}{l}47 \\
12.1\end{array}$ & $\begin{array}{l}21 \\
5.4\end{array}$ & $\begin{array}{l}28 \\
7.2\end{array}$ & 4.17 & 1.26 & High \\
\hline 1 & $\begin{array}{l}\text { I use social media (Twitter, } \\
\text { Snapchat, Instagram, Facebook, } \\
\text { etc.) as an effective way to } \\
\text { communicate with others. }\end{array}$ & $\begin{array}{l}\text { Frequency } \\
\%\end{array}$ & $\begin{array}{l}227 \\
58.5\end{array}$ & $\begin{array}{l}51 \\
13.1\end{array}$ & $\begin{array}{l}51 \\
13.1\end{array}$ & $\begin{array}{l}17 \\
4.4\end{array}$ & $\begin{array}{l}42 \\
10.8\end{array}$ & 4.04 & 1.37 & High \\
\hline 3 & I'm good at using social media. & $\begin{array}{l}\text { Frequency } \\
\%\end{array}$ & $\begin{array}{l}198 \\
51.0\end{array}$ & $\begin{array}{l}78 \\
20.1\end{array}$ & $\begin{array}{l}56 \\
14.4\end{array}$ & $\begin{array}{l}27 \\
7.0\end{array}$ & $\begin{array}{l}29 \\
7.5\end{array}$ & 4.00 & 1.27 & High \\
\hline 9 & $\begin{array}{l}\text { I use websites to get important } \\
\text { information for me. }\end{array}$ & $\begin{array}{l}\text { Frequency } \\
\%\end{array}$ & $\begin{array}{l}198 \\
52.0\end{array}$ & $\begin{array}{l}72 \\
18.9\end{array}$ & $\begin{array}{l}52 \\
13.6\end{array}$ & $\begin{array}{l}30 \\
7.9\end{array}$ & $\begin{array}{l}29 \\
7.6\end{array}$ & 4.00 & 1.29 & High \\
\hline 13 & $\begin{array}{l}\text { I use the internet to help myself } \\
\text { find good information about } \\
\text { products, services and games. }\end{array}$ & $\begin{array}{l}\text { Frequency } \\
\%\end{array}$ & $\begin{array}{l}207 \\
53.4\end{array}$ & $\begin{array}{l}70 \\
18.0\end{array}$ & $\begin{array}{l}49 \\
12.6\end{array}$ & $\begin{array}{l}27 \\
7.0\end{array}$ & $\begin{array}{l}35 \\
9.0\end{array}$ & 4.00 & 1.32 & High \\
\hline 11 & $\begin{array}{l}\text { I can use the internet to answer } \\
\text { my questions in a useful way. }\end{array}$ & $\begin{array}{l}\text { Frequency } \\
\%\end{array}$ & $\begin{array}{l}185 \\
48.2\end{array}$ & $\begin{array}{l}74 \\
19.3\end{array}$ & $\begin{array}{l}68 \\
17.7\end{array}$ & $\begin{array}{l}31 \\
8.1\end{array}$ & $\begin{array}{l}26 \\
6.8\end{array}$ & 3.94 & 1.26 & High \\
\hline 6 & $\begin{array}{l}\text { I feel a lot happier when using } \\
\text { websites. }\end{array}$ & $\begin{array}{l}\text { Frequency } \\
\%\end{array}$ & $\begin{array}{l}188 \\
48.5\end{array}$ & $\begin{array}{l}72 \\
18.6\end{array}$ & $\begin{array}{l}62 \\
16.0\end{array}$ & $\begin{array}{l}29 \\
7.5\end{array}$ & $\begin{array}{l}37 \\
9.5\end{array}$ & 3.89 & 1.34 & High \\
\hline 5 & $\begin{array}{l}\text { I get interesting information by } \\
\text { reading what other people post. }\end{array}$ & $\begin{array}{l}\text { Frequency } \\
\%\end{array}$ & $\begin{array}{l}157 \\
39.9\end{array}$ & $\begin{array}{l}97 \\
24.7\end{array}$ & $\begin{array}{l}70 \\
17.8\end{array}$ & $\begin{array}{l}37 \\
9.4\end{array}$ & $\begin{array}{l}32 \\
8.1\end{array}$ & 3.79 & 1.28 & High \\
\hline 7 & $\begin{array}{l}\text { I can make others happy by } \\
\text { using websites. }\end{array}$ & $\begin{array}{l}\text { Frequency } \\
\%\end{array}$ & $\begin{array}{l}160 \\
41.3\end{array}$ & $\begin{array}{l}85 \\
22.0\end{array}$ & $\begin{array}{l}55 \\
14.2\end{array}$ & $\begin{array}{l}47 \\
12.1\end{array}$ & $\begin{array}{l}40 \\
10.3\end{array}$ & 3.72 & 1.38 & High \\
\hline 4 & $\begin{array}{l}\text { I can have a positive impact on } \\
\text { the lives of others through } \\
\text { social networks. }\end{array}$ & $\begin{array}{l}\text { Frequency } \\
\%\end{array}$ & $\begin{array}{l}162 \\
41.3\end{array}$ & $\begin{array}{l}68 \\
17.3\end{array}$ & $\begin{array}{l}84 \\
21.4\end{array}$ & $\begin{array}{l}26 \\
6.6\end{array}$ & $\begin{array}{l}52 \\
13.3\end{array}$ & 3.67 & 1.41 & High \\
\hline 10 & $\begin{array}{l}\text { I engage positively in using the } \\
\text { Internet by answering others' } \\
\text { questions in a beneficial way. }\end{array}$ & $\begin{array}{l}\text { Frequency } \\
\%\end{array}$ & $\begin{array}{l}142 \\
37.1\end{array}$ & $\begin{array}{l}78 \\
20.4\end{array}$ & $\begin{array}{l}67 \\
17.5\end{array}$ & $\begin{array}{l}52 \\
13.6\end{array}$ & $\begin{array}{l}44 \\
11.5\end{array}$ & 3.58 & 1.40 & High \\
\hline 12 & $\begin{array}{l}\text { I organize the information I } \\
\text { find online so that it is } \\
\text { interlinked and answers } \\
\text { specific questions. }\end{array}$ & $\begin{array}{l}\text { Frequency } \\
\%\end{array}$ & $\begin{array}{l}132 \\
34.6\end{array}$ & $\begin{array}{l}74 \\
19.4\end{array}$ & $\begin{array}{l}82 \\
21.5\end{array}$ & $\begin{array}{l}50 \\
13.1\end{array}$ & $\begin{array}{l}44 \\
11.5\end{array}$ & 3.52 & 1.38 & High \\
\hline 2 & $\begin{array}{l}\text { I write posts on social networks } \\
\text { (Twitter, Snapchat, Instagram, } \\
\text { Facebook, blogs, etc.) that } \\
\text { others are interested in and } \\
\text { search for. }\end{array}$ & $\begin{array}{l}\text { Frequency } \\
\%\end{array}$ & $\begin{array}{l}147 \\
37.9\end{array}$ & $\begin{array}{l}52 \\
13.4\end{array}$ & $\begin{array}{l}77 \\
19.8\end{array}$ & $\begin{array}{l}48 \\
12.4\end{array}$ & $\begin{array}{l}64 \\
16.5\end{array}$ & 3.44 & 1.50 & High \\
\hline 8 & $\begin{array}{l}\text { I use websites to get important } \\
\text { information for others. }\end{array}$ & $\begin{array}{l}\text { Frequency } \\
\%\end{array}$ & $\begin{array}{l}127 \\
33.0\end{array}$ & $\begin{array}{l}67 \\
17.4\end{array}$ & $\begin{array}{l}83 \\
21.6\end{array}$ & $\begin{array}{l}47 \\
12.2\end{array}$ & $\begin{array}{l}61 \\
15.8\end{array}$ & 3.39 & 1.45 & Average \\
\hline \multicolumn{2}{|c|}{ * General average } & & & & & & & 3.79 & 0.87 & High \\
\hline
\end{tabular}

It is clear from Table 6 that the research sample had a high level of Internet self-efficacy, and all items received (high) level except for item 8 that was of an average level, namely 'I use websites to get important information for others', and the research does not consider this a negative point, as it is actually related to items 2 and 4 .

\section{Second research question}

The second research question was: are there differences between the level of availability of digital citizenship standards for students, according to the educational stage? To answer this question, a t-test was applied to show the differences between two independent groups. Table 7 shows the result of the t-test. 
Table 7. t-test for the significance of differences in the level of availability of digital citizenship standards for students according to the different educational stage

\begin{tabular}{lllllll}
\hline Domain & Educational stage & $\mathrm{N}$ & $\mathrm{M}$ & $\mathrm{SD}$ & $\mathrm{t}$-value & Significance \\
\hline Digital Identity Management & Middle School & 275 & 3.95 & 0.56 & 3.64 & 0.000 \\
& Secondary school & 119 & 3.72 & 0.61 & & \multirow{2}{*}{0.499} \\
Engaging in Positive, Safe, Legal and Ethical & Middle School & 275 & 3.63 & 0.50 & 0.68 & \\
Behavior & Secondary school & 119 & 3.67 & 0.46 & & \multirow{2}{*}{0.504} \\
Respect for Intellectual Property Rights & Middle School & 275 & 3.66 & 0.70 & 0.67 & \\
& Secondary school & 119 & 3.72 & 0.66 & \multirow{2}{*}{0.997} \\
Maintaining Digital Privacy and Security & Middle School & 275 & 3.86 & 0.78 & 0.00 & \\
& Secondary school & 119 & 3.86 & 0.69 & \multirow{2}{*}{0.583} \\
Total degree for the level of availability of & Middle School & 275 & 3.76 & 0.49 & 0.55 & \\
digital citizenship standards & Secondary school & 119 & 3.74 & 0.43 & & \\
\hline
\end{tabular}

Table 7 shows that t-values are not significant in the domains: engaging in positive, safe, legal and ethical behavior; Intellectual property rights respect; preserving digital privacy and security; and in the total degree of the level of availability of digital citizenship standards, which indicates that there were no statistically significant differences in the level of availability of digital citizenship among the sample in those aspects due to the different educational stage, and this can be attributed to the fact that all students are in adolescence, and this result is similar to Webster (2018) regarding the absence of differences in digital citizenship among students in their classes.

However, Table 7 shows that were statistically significant differences between the sample in the domain of 'digital identity management' domain in different educational stages. And those differences were in favor of middle school students, and this result can be attributed to the fact that middle school students do not have an in-depth use of social media, or deal with topics that contribute to a sense of responsibility towards their digital identity, unlike high school students who have greater exposure to social networks and communicating with others, knowing what is being sent and what should not be sent, and therefore may be more likely to not maintain a digital identity.

Regarding the differences between the level of availability of digital citizenship standards for students according to the difference in the average daily use of technology variable, Table 8 shows the distribution of the sample according to their average daily use of digital devices as shown in.

Table 8. Distribution of the sample of students according to their average daily use of digital devices

\begin{tabular}{lll}
\hline Average daily use of digital devices & Percentage & Number \\
\hline Less than hour & $18.8 \%$ & 74 \\
1 hour to less than 5 hours & $41.6 \%$ & 164 \\
+5 hours & $38.8 \%$ & 153 \\
Unspecified & $0.8 \%$ & 3 \\
Total & $100 \%$ & 394 \\
\hline
\end{tabular}

A one-way ANOVA test was conducted to identify differences between students' level of digital citizenship according to the difference in average daily use of the technology. Table 9 shows the result obtained from the statistical analysis.

Table 9. One-way ANOVA test for the significance of differences in the level of availability of digital citizenship standards for students according to the average daily use of digital devices

\begin{tabular}{|c|c|c|c|c|c|c|}
\hline Domain & Source of variance & Sum of squares & df & Mean square & $\mathrm{P}$ & Significance \\
\hline \multirow{2}{*}{ Digital Identity Management } & Between groups & 6.98 & 2 & 3.49 & \multirow[t]{2}{*}{10.90} & \multirow[t]{2}{*}{0.000} \\
\hline & within groups & 124.19 & 388 & 0.32 & & \\
\hline Engaging in Positive, Safe, Legal and & Between groups & 0,83 & 2 & 0,41 & \multirow[t]{2}{*}{1,73} & \multirow[t]{2}{*}{0,178} \\
\hline Ethical Behavior & within groups & 92,49 & 388 & 0,24 & & \\
\hline \multirow[t]{2}{*}{ Respect for Intellectual Property Rights } & Between groups & 1,86 & 2 & 0,93 & \multirow[t]{2}{*}{1,96} & \multirow[t]{2}{*}{0,142} \\
\hline & within groups & 183,89 & 388 & 0,47 & & \\
\hline \multirow{2}{*}{ Maintaining Digital Privacy and Security } & Between groups & 4,48 & 2 & 2.24 & \multirow[t]{2}{*}{4.04} & \multirow[t]{2}{*}{0,018} \\
\hline & within groups & 214,74 & 388 & 0.55 & & \\
\hline \multirow{2}{*}{$\begin{array}{l}\text { Total degree for the level of availability } \\
\text { of digital citizenship standards }\end{array}$} & Between groups & 1,02 & 2 & 0,51 & \multirow[t]{2}{*}{2.33} & \multirow[t]{2}{*}{0,098} \\
\hline & within groups & 84,88 & 388 & 0.22 & & \\
\hline
\end{tabular}


It is clear from Table 9 that there are no statistically significant differences in the level of availability of digital citizenship among students in the domains: engaging in positive, safe, legal and ethical behavior; intellectual property rights respect; and in the total degree of the level of availability of digital citizenship standards, indicating that the amount of time students spend online or on their devices has no effect on the level of their digital citizenship practices. However, there were statistically significant differences between the students based on the average daily use of digital devices in the domains: digital identity management; and maintaining digital privacy and security. Al-Zahrani (2015) confirmed that the difference in the average daily use of technology affects the level of digital citizenship for the student.

To identify the differences between the level of availability of digital citizenship standards for students, according to the difference in the number of social networks that they subscribe to, Table 10 shows the distribution of the sample according to the types of social networks they are subscribed to, with the ability of the student to choose more than one social network at the same time.

Table 10. Distribution the sample of students according to the social networks they are subscribed to

\begin{tabular}{lll}
\hline Social media accounts & Percentage & Number \\
\hline He has no social contact & $4,1 \%$ & 16 \\
Facebook & $34,8 \%$ & 137 \\
Twitter & $48,2 \%$ & 190 \\
Instagram & $75,9 \%$ & 299 \\
WhatsApp & $83,2 \%$ & 328 \\
Snapchat & $79,9 \%$ & 315 \\
Other applications & $43,4 \%$ & 171 \\
Sample individuals' number & 394 & \\
\hline
\end{tabular}

A one-way ANOVA test (Table 11) was conducted to identify the differences according to the difference in the research variables the number of social networks they are subscribed to.

Table 11. one-way ANOVA test to indicate the differences in the level of availability of digital citizenship standards for students according to their number of social media accounts

\begin{tabular}{|c|c|c|c|c|c|c|}
\hline Domain & Source of variance & Sums of squares & $\mathrm{df}$ & Mean square & P-value & Significance \\
\hline \multirow[t]{2}{*}{ Digital Identity Management } & Between groups & 3.58 & 3 & 1,19 & \multirow[t]{2}{*}{3.61} & \multirow[t]{2}{*}{0.014} \\
\hline & within groups & 129.19 & 390 & 0.33 & & \\
\hline \multirow{2}{*}{$\begin{array}{l}\text { Engaging in Positive, Safe, Legal and Ethical } \\
\text { Behavior }\end{array}$} & Between groups & 2.33 & 3 & 0.78 & \multirow[t]{2}{*}{3.29} & \multirow[t]{2}{*}{0.021} \\
\hline & within groups & 91,90 & 390 & 0,24 & & \\
\hline \multirow[t]{2}{*}{ Respect for Intellectual Property Rights } & Between groups & 1.14 & 3 & 0,38 & \multirow[t]{2}{*}{0.80} & \multirow[t]{2}{*}{0.496} \\
\hline & within groups & 185.86 & 390 & 0.48 & & \\
\hline \multirow[t]{2}{*}{ Maintaining Digital Privacy and Security } & Between groups & 6.74 & 3 & 2.25 & \multirow[t]{2}{*}{4.04} & \multirow[t]{2}{*}{0.008} \\
\hline & within groups & 216.74 & 390 & 0.56 & & \\
\hline \multirow[t]{2}{*}{ Total degree for the level of availability of standards } & Between groups & 1.78 & 3 & 0.60 & \multirow[t]{2}{*}{2.74} & \multirow[t]{2}{*}{0.043} \\
\hline & within groups & 84.76 & 390 & 0.22 & & \\
\hline
\end{tabular}

It is evident from Table 11 that there were statistically significant differences in the level of availability of digital citizenship standards among students due to the difference in the number of accounts of social networks in those domains: digital identity management; engaging in positive, safe, legal, and ethical behavior; maintaining digital privacy and security; and in the overall degree of level of availability of digital citizenship standards. However, there were no statistically significant differences in the domain intellectual property rights respect. These findings are consistent with what was found in Tables 8 and 10 .

\section{The relationship between digital citizenship and Internet self-efficacy}

Pearson correlation coefficient was calculated to measure the relationship between the sample availability of digital citizenship standards and their scores in the Internet self-efficacy scale. Table 12 shows the results. 
Table 12. Pearson correlation coefficients for measuring the relation between the level of availability of digital citizenship standards and their internet self-efficiency $(n=394)$

\begin{tabular}{lll}
\hline Domains & Correlation Coefficient & Significance level \\
\hline Digital Identity Management & 0.0490 & Not significant \\
Engaging in Positive, Safe, Legal and Ethical Behavior & 0.4570 & Significant at the level of 0.01 \\
Respect for Intellectual Property Rights & 0.3947 & Significant at the level of 0.01 \\
Maintaining Digital Privacy and Security & 0.5185 & Significant at the level of 0.01 \\
Total degree for the scale of level of availability of digital citizenship & 0.5014 & Significant at the level of 0.01 \\
standards & & \\
\hline
\end{tabular}

As shown in Table 12, there were direct positive correlation between the total score of the internet self-efficacy scale and the domains of the level of availability of digital citizenship standards: Engaging in Positive, Safe, Legal and Ethical Behavior, Respect for Intellectual Property Rights, Maintaining Digital Privacy and Security. This indicates that the higher the level of internet self-efficacy in the sample, the higher the level of availability of digital citizenship standards in those domains. This finding is consistent with that of Al-Zahrani (2015). However, as can be seen in Table 12, there was no correlation between the total score of the internet self-efficacy scale and the domain of: Digital Identity Management. Nonetheless, there was a statistically significant positive correlation between the total internet self-efficacy score and total degree of level of availability of digital citizenship standards. The result is consistent with the study of De Marco, Robles, and Antino (2014) and of Kim and Choi (2018).

\section{Recommendations}

Based on the findings of the study, the following is recommended:

1) Teachers should be encouraged to highlight the importance of digital identity for students, and the importance of showing positive and effective behavior.

2) The need to Raise awareness of the harms of e-bullying, and the necessity of enforcing Anti-Cyber Crime Law in this matter.

3) Disseminating the concept of digital citizenship in the educational field, and introducing its elements, standards, practices, the benefits of using technology positively and beneficially, and the detriment that may arise from misuse.

4) Providing students with awareness sessions on the protection of intellectual property rights.

5) Enhancing the safety and protection of students during the teaching process.

6) Including the uses of different social media in curricula, and their use by teachers to collaborate with students during classes, and in the work of activities and practical tasks for the purpose of raising internet self-efficacy.

\section{Future research}

1) Carrying out similar study of a female sample to compensate for the limitations of this study.

\section{References}

Al-Asiri, A. S. (2017). The Reality of Promoting Digital Citizenship for Female Students of Imam Mohammad Ibn Saud Islamic University. An unpublished master's degree thesis. Imam Mohammad Ibn Saud Islamic University, Riyadh.

Al-Dosari, F. F. (2017). The level of availability of digital citizenship standards for computer teachers. Journal of Curriculum and Teaching, 219, 107-240.

Al-Jazzar, H. H. (2014). The role of the educational institution in inculcating the values of digital citizenship: a suggested proposal. Journal of Arab Studies in Education and Psychology, 65, 385-418.

Al-Mallah, T. E.-M. (2017). Digital Citizenship. Cairo, Egypt: Dar El Sahab for Publishing and Distributing.

Al-Muslamani, L. I. (2014). Education and Digital Citizenship: a proposed vision. Education World Magazine, 47, 15-94.

Al-Qaid, M. (2014, February 20). Digital Citizenship [weblog post]. Retrieved from http://www.new-educ.com/definition-of-digital-citizenship

Al-Zahrani, A. (2015). Toward Digital Citizenship: Examining Factors Affecting Participation and Involvement in the Internet Society among Higher Education Students. International Education Studies, 8, 203-217. 
https://doi.org/10.5539/ies.v8n12p203

Azzeddine, R. (2016). ICT Obliteration of National Identity-A Case Study of Arab Societies. Journal of Human and Social Sciences, 20, 231-221.

Bureau of Experts at The Council of Ministers. (2007). Anti-Cyber Crime Law. Retrieved September 23, 2018, from https://www.boe.gov.sa/m/viewsubsystemdetails.aspx?lang=ar\&systemid=217

Common Sense Media. (2016). Our K-12 Digital Citizenship Curriculum. Retrieved September 19, 2018, from https://www.commonsensemedia.org/sites/default/files/uploads/classroom_curriculum/cs_digitalcitizenship curric_2016_release.pdf

De Marco, S., Robles, J. M., \& Antino, M. (2014). Digital skills as a conditioning factor for digital political participation. Communications, 39(1), 43-65. https://doi.org/10.1515/commun-2014-0004

Feher, K. (2017). Netframework and the digitalizedmediatized self. Corvinus Jornal of Sociology and Social Policy, 8(1), 111-126. https://doi.org/10.14267/CJSSP.2017.01.06

General Authority for Statistics. (2019). Bulletin of Individuals and Households' ICT Access and Usage Survey, 2019. Retrieved April 17, 2020, from https://www.stats.gov.sa/sites/default/files/nshr_msh_nfdh_wstkhdm_tqny_lmlwmt_wltslt_llsr_wlfrd_2019 m_0.pdf

Ikeepsafe. (n.d.). Digital Citizenship Program. Digital Citizenship. Retrieved September 23, 2020, from https://ikeepsafe.org/products/

ISTE. (2019). ISTE Standard. Retrieved September 19 , 2018, from https://www.iste.org/explore/categorylist?code=Digital+citizenship

Jones, L. M., \& Mitchell, K. J. (2016). Defining and measuring youth digital citizenship. New Media \& Society, 18, 1807-1816. https://doi.org/10.1177/1461444815577797

Kim, M., \& Choi, D. (2018). Development of Youth Digital Citizenship Scale and Implication for Educational Setting. Educational Technology \& Society, 21, 155-171. https://doi.org/10.1037/t69727-000

Kim, Y., \& Glassman, M. (2013). Beyond search and communication: Development and validation of the Internet Self-efficacy Scale (ISS). Computers in Human Behavior, 29(4), 1421-1429. https://doi.org/10.1016/j.chb.2013.01.018

Lamushi, Z. (2016, April). Activating the E-Learning System as a Mechanism to Raise the Level of Performance in Universities in Light of Information Technology. Paper submitted to the Eleventh International Conference: Learning in the Digital Technology Era by Jil Scientific Research Center, Tripoli, Lebanon.

Lindsey, L. (2015). Preparing Teacher Candidates for 21st Century Classrooms: A Study of Digital Citizenship. Doctoral thesis, Arizona State University, Arizona, United State. Retrieved September 19, 2018, from http://hdl.handle.net/2286/R.A.150461

Lyons, K. (2012). Investigating Student Gender and Grade Level Differences in Digital Citizenship Behavior. Doctoral thesis, Walden University, Minnesota, United State. Retrieved July 22, 2019, from https://scholarworks.waldenu.edu/dissertations/1015/

NetSafe. (n. d.). Online safety for New Zealand. Retrieved September 23, 2018, from https://www.netsafe.org.nz/digital-citizenship-schools/digital-citizenship/

Nordin, M. (2015). Self-Regulated Digital Citizen: A Survey of Malaysian Undergraduates. Research Journal of Social Sciences, 8, 20-24.

NSW Government. (n. d.). Digital Citizenship. Retrieved September 23, 2020, from https://www.digitalcitizenship.nsw.edu.au/

Orth, D., \& Chen, E. (2013). The strategy for digital citizenship: Guiding our children in a digital world. National Association of Independent Schools, 72, 56-63.

Payne, J. L. (2016). A case study of teaching digital citizenship in fifth grade. Doctoral thesis, The University of Alabama, Alabama, United State. Retrieved September 19, 2018, from https://search.proquest.com/docview/1877914633

Pescetta, M. (2011). Teaching Digital Citizenship in a Global Academy. Doctoral thesis, Nova Southeastern University, FL, United State. Retrieved September 19, 2018, from https://search.proquest.com/docview/910473347 
Prensky, M. (2001). Digital natives, digital immigrants. On the Horizon, 9(5), 1-6. https://doi.org/10.1108/10748120110424816

Ribble, M. (2012/2007). Digital Citizenship in Schools. Arab Bureau of Education for the Gulf States translated. Riyadh, Kingdom of Saudi Arabia: Arab Bureau of Education for the Gulf States.

Saudi Vision 2030. (2016a). National Transformation Program 2020. Retrieved September 23, 2018, from https://vision2030.gov.sa/ar/programs/NTP

Saudi Vision 2030. (2016b). Vision 2030 file. Retrieved September 23, 2018, from https://vision2030.gov.sa/ar

Sharma, B. (2016). A focus on reliability in developmental research through Cronbach's Alpha among medical. dental and paramedical professionals. Asian Pac. J. Health Sci., 3(4), 271-278. https://doi.org/10.21276/apjhs.2016.3.4.43

Webster, J. P. (2018). Teacher Perceptions and Implementation of Digital Citizenship Curriculum in One-To-One High Schools in Missouri. Doctoral thesis, Southwest Baptist University, Missouri, United State. Retrieved September 19, 2018, from https://search.proquest.com/docview/2030058672?accountid=142908

\section{Copyrights}

Copyright for this article is retained by the author, with first publication rights granted to the journal.

This is an open-access article distributed under the terms and conditions of the Creative Commons Attribution license (http://creativecommons.org/licenses/by/4.0/). 